\title{
IMPROVED AQUA REGIA METAL EXTRACTION USING A LOAM SOIL CRM ERC-CC141 AND A PERFORMANT MICROWAVE OVEN
}

\author{
Nicoleta Mirela Marin ${ }^{1,2}$, Gabriela Geanina Vasile1, Jana Petre1, \\ Liliana Valeria Cruceru ${ }^{1}$ \\ ${ }^{1}$ National Research and Development Institute for Industrial Ecology - Bucharest, 71- \\ 73 Podul Dambovitei Street, 060650, Bucharest, Romania \\ e-mail: nicoleta.marin@incdecoind.ro \\ ${ }^{2}$ Department of Analytical Chemistry, Faculty of Chemistry, University of Bucharest, \\ 2-14 Blvd. Regina Elisabeta, 030018, Bucharest, Romania,
}

\begin{abstract}
In this study a digestion method for determination of metals ( $\mathrm{Co}, \mathrm{Cr}, \mathrm{Cu}, \mathrm{Ni}, \mathrm{Pb}, \mathrm{Zn}$ ) in soil aqua regia extracts was performed using a microwave digestion technique combined with ICP-EOS and FAAS techniques. Improved digestion program was applied in three steps at $220^{\circ} \mathrm{C}$ maximum temperature for 35 minutes to $1 \mathrm{~g}$ of soil with a mixture of $\mathrm{HCl}$ and $\mathrm{HNO}_{3}$ (report $6 \mathrm{~mL}$ to $2 \mathrm{~mL}$ ). In experimental studies was used a Certified Reference Material CRM ERC-CC141 loam soil. The recovery percentages in CRM standard were situated for all metals in the range $93.5 \%$ to $105 \%$ for ICP-EOS determinations and $92 \%$ to $107 \%$ for FAAS determinations.
\end{abstract}

Keywords: soil, metals, microwave digestion methods, ICP-EOS, FAAS

\section{Introduction}

Normally in the soil there are small amounts of metals, but sometimes their levels increased due to the anthropic sources and industrial pollution. The soil behaves as a deposit for the metallic elements due to its high accumulation capacity during the time. Based on the above observations, the monitoring of the metals in this type of matrix is important [1-5].

Accurate determinations of metals în soil samples lead to development and / or improvement of digestion methods as well as choosing appropiate technique for obtaining reproducible results. Microwave assisted digestion provides a fast and suitable method for soil complex matrices [5-9].

The objectives of the present study are: (i) optimization of a microwave digestion method for determination of metals in CRM soil using Flame Atomic Absorbtion Spectrometry (FAAS) and Inductively Coupled Plasma with Optical Emission Spectrometry (ICP-EOS) techniques. (ii) extending the application of this method for agricultural and industrial soil samples.

\section{Materials and Methods}

\subsection{Equipments}

FAAS Thermo Scientific M6 Dual Spectrometer and the ICP-OES Optima 5300 DV Perkin Elmer Spectrometer were used for determination of $\mathrm{Co}, \mathrm{Cr}, \mathrm{Cu}, \mathrm{Ni}$, $\mathrm{Pb}$ and $\mathrm{Zn}$ concentrations. The digestion of samples was done with a Microwave Digestion System Ethos Up Milestone. 


\subsection{Reagents and calibration}

The acids used, hydrocloric acid $37 \%$ and nitric acids $67 \%$, were reagent quality from Merk.

Ulta-purity water was produced with a Millipore Milli-Q System.

For the calibration curves were prepared standards în the range 0.5 to $2.5 \mathrm{mg} / \mathrm{L}$ using a $100 \mathrm{mg} / \mathrm{L}$ Multielement Certified Referince Material (ICP multielement standard solution XVI, Certipur, Merck) for ICP-EOS technique. For FAAS determination were used unielement standards for AAS, the calibration curves were ploted in the range 1 to $8 \mathrm{mg} / \mathrm{L}$. For the matrix solution, the standards were prepared with aqua regia in the same proportion as was used for digestion step. Quality control of the analytical results was performed with a multielement Certified Referince Material for ICP, $1000 \mathrm{mg} / \mathrm{L}$, Merck quality.

FAAS analytical determinations using an air-acetylene flame were carried out based on the wavelengths presented in Table 1. ICP-EOS parameters were presented in Table 2.

Table 1. The adsorption and emission lines used in FAAS and ICP-OES

\begin{tabular}{ccc}
\hline Metal & $\begin{array}{c}\text { FAAS } \\
\text { Wavelength }(\mathrm{nm})\end{array}$ & $\begin{array}{c}\text { ICP-OES } \\
\text { Wavelength }(\mathrm{nm})\end{array}$ \\
\hline $\mathrm{Pb}$ & 217.0 & 220.353 \\
\hline $\mathrm{Co}$ & 240.7 & 228.616 \\
\hline $\mathrm{Cr}$ & 357.9 & 267.716 \\
\hline $\mathrm{Cu}$ & 324.8 & 327.393 \\
\hline $\mathrm{Ni}$ & 232.0 & 231.604 \\
\hline $\mathrm{Zn}$ & 213.9 & 206.200 \\
\hline
\end{tabular}

Table 2. Spectrometer operating parameters

\begin{tabular}{lrlr}
\hline \multicolumn{4}{c}{ ICP-OES Spectrometer parameters } \\
\hline Delay time: & $40 \mathrm{~s}$ & Purge gas flow: & normal \\
\hline Replicates & 2 times & Peristaltic pump: & $1.5 \mathrm{~mL} / \mathrm{min}$ \\
\hline \multicolumn{4}{c}{ Plasma parameters } \\
\hline Plasma flow rate: & $15 \mathrm{~L} / \mathrm{min}$ & Power RF: & $1400 \mathrm{~W}$ \\
\hline Auxiliar flow rate: & $0.2 \mathrm{~L} / \mathrm{min}$ & Plasma view: & axial \\
\hline Nebulizer flow rate: $0.7 \mathrm{~L} / \mathrm{min}$ & View distance: & $15.0 \mathrm{~mm}$ \\
\hline \multicolumn{4}{c}{ Spectral peak processing } \\
\hline Peak algorithm: & Peak area & Points per peak: & 7 points \\
\hline
\end{tabular}

\subsection{Aqua regia extraction}

Over $1 \mathrm{~g}$ of CRM sample was added $2 \mathrm{ml} \mathrm{HNO}_{3}$ and $6 \mathrm{~mL} \mathrm{HCl}$, samples were weighed into microwave oven vessels and placed în the microwave oven. In order to obtained suitable extracts was performed a multi-steps digestion program: for 15 minutes the temperature inside the vessels was increased to $220^{\circ} \mathrm{C}$, then was keept for 20 minutes at $220^{\circ} \mathrm{C}$ and the cooling process was applied for 30 minutes. The steps of the digestion program is given in table 3 . After cooled, the solutions were filtered on 0,45 $\mu \mathrm{m}$ porosity paper in $50 \mathrm{~mL}$ volumetric flasks and were analysed with FAAS and ICPEOS techniques. Temperature $T_{2}$ is controlled outside of the reaction vessels by an IR sensor. 
Table 3. Digestion program

\begin{tabular}{ccccc}
\hline Step & $\mathbf{T}_{\mathbf{1}}{ }^{\circ} \mathbf{C}$ & $\mathbf{T}_{\mathbf{2}}{ }^{\circ} \mathbf{C}$ & Power $(\mathbf{W})$ & Time (min) \\
\hline 1 & 220 & 120 & 1800 & 15 \\
\hline 2 & 220 & 120 & 1800 & 20 \\
\hline 3 & cooled & cooled & - & 30 \\
\hline
\end{tabular}

\section{Results and Discussion}

In order to evaluate the extraction procedure, the obtained experimental values were compared with certified results of the CRM ERC-CC141 loam soil. In table 4 and 5 are presented comparative results for both techniques apllied. The recovery percentages obtained suggests that the method is adequate for intended purpose.

Table 4. Determinations of metals in loam soil using ICP

\begin{tabular}{cccc}
\hline \multirow{2}{*}{$\begin{array}{c}\text { Metallic } \\
\text { elements }\end{array}$} & $\begin{array}{c}\text { CRM ERC-CC141 loam soil } \\
\text { Obtained value } \\
\text { mg/kg d.m.. }\end{array}$ & $\begin{array}{c}\text { Certified value } \\
\text { mg/kg d.m. }\end{array}$ & $\begin{array}{c}\text { Recovery } \\
(\%)\end{array}$ \\
\hline $\mathrm{Pb}$ & $30.1 \pm 3.6$ & $32.2 \pm 4.0$ & 93.5 \\
\hline $\mathrm{Co}$ & $8.20 \pm 1.0$ & $7.90 \pm 0.90$ & 104 \\
\hline $\mathrm{Cr}$ & $30.5 \pm 5.3$ & $31.0 \pm 4.0$ & 98.0 \\
\hline $\mathrm{Cu}$ & $12.5 \pm 1.4$ & $12.4 \pm 0.9$ & 101 \\
\hline $\mathrm{Ni}$ & $21.4 \pm 2.3$ & $21.9 \pm 1.6$ & 98.0 \\
\hline $\mathrm{Zn}$ & $51.1 \pm 5.4$ & $50.0 \pm 4.0$ & 102 \\
\hline
\end{tabular}

*dry matter

Table 5. Determinations of metals in loam soil using FAAS

\begin{tabular}{cccc}
\hline \multirow{2}{*}{$\begin{array}{c}\text { Metallic } \\
\text { elements }\end{array}$} & $\begin{array}{c}\text { CRM ERC-CC141 loam soil } \\
\text { Obtained value } \\
\text { mg/kg d.m. }\end{array}$ & $\begin{array}{c}\text { Certified value } \\
\text { mg/kg d.m. }\end{array}$ & $\begin{array}{c}\text { Recovery } \\
(\%)\end{array}$ \\
\hline $\mathrm{Pb}$ & $29.6 \pm 3.5$ & $32.2 \pm 4.0$ & 92 \\
\hline $\mathrm{Co}$ & $7.70 \pm 0.96$ & $7.90 \pm 0.90$ & 97 \\
\hline $\mathrm{Cr}$ & $31.6 \pm 4.9$ & $31.0 \pm 4.0$ & 102 \\
\hline $\mathrm{Cu}$ & $11.6 \pm 1.3$ & $12.4 \pm 0.9$ & 93 \\
\hline $\mathrm{Ni}$ & $21.6 \pm 2.0$ & $21.9 \pm 1.6$ & 99 \\
\hline $\mathrm{Zn}$ & $53.4 \pm 5.0$ & $50.0 \pm 4.0$ & 107 \\
\hline
\end{tabular}

*dry matter

The improved digestion method was applied to eight soil samples collected from 0 to 5 $\mathrm{cm}$ depth from an industrial area situated in Ilfov region. The samples were analyzed both with FAAS and ICP-EOS techniques and the results for the metals content are presented in table 6 and 7 . Both techniques provide similar results in the range of associated measurement uncertainty. The values of $\mathrm{Co}, \mathrm{Cr}$ and $\mathrm{Zn}$ are within the normal values according with Romanian legislation for soil quality [10]. The results obtained for $\mathrm{Pb}, \mathrm{Ni}$ and $\mathrm{Cu}$ are over normal values, but were below the alert threshold for industrial samples. 
Table 6. Determinations of metals in industrial soil by ICP-OES

\begin{tabular}{cccccccccc}
\hline $\begin{array}{c}\text { Metallic } \\
\text { elements }\end{array}$ & Unit & $\begin{array}{c}\text { Normal } \\
\text { Values }\end{array}$ & S1 & S2 & S3 & S4 & S5 & S6 & S7 \\
\hline $\mathrm{Pb}$ & $\mathrm{mg} / \mathrm{kg}$ d.m. & 20 & 26.7 & 23.3 & 14.0 & 9.04 & 10.7 & 16.0 & 13.6 \\
\hline $\mathrm{Co}$ & $\mathrm{mg} / \mathrm{kg}$ d.m. & 15 & 7.43 & 8.77 & 9.88 & 7.71 & 8.84 & 7.81 & 9.26 \\
\hline $\mathrm{Cr}$ & $\mathrm{mg} / \mathrm{kg}$ d.m. & 30 & 22.7 & 28.2 & 35.2 & 18.5 & 31.4 & 14.4 & 21.0 \\
\hline $\mathrm{Cu}$ & $\mathrm{mg} / \mathrm{kg}$ d.m. & 20 & 39.5 & 36.4 & 45.7 & 23.0 & 40.3 & 20.2 & 23.1 \\
\hline $\mathrm{Ni}$ & $\mathrm{mg} / \mathrm{kg}$ d.m. & 20 & 27.7 & 43.2 & 41.7 & 26.5 & 32.8 & 24.4 & 29.1 \\
\hline $\mathrm{Zn}$ & $\mathrm{mg} / \mathrm{kg}$ d.m. & 100 & 99.1 & 97.5 & 65.6 & 40.2 & 51.5 & 54.3 & 53.8 \\
\hline
\end{tabular}

Table 7. Determinations of metals in industrial soil by FAAS

\begin{tabular}{cccccccccc}
\hline $\begin{array}{c}\text { Metallic } \\
\text { elements }\end{array}$ & Unit & $\begin{array}{c}\text { Normal } \\
\text { Values }\end{array}$ & S1 & S2 & S3 & S4 & S5 & S6 & S7 \\
\hline $\mathrm{Pb}$ & $\mathrm{mg} / \mathrm{kg}$ d.m. & 20 & 27.7 & 24.3 & 14.9 & 9.20 & 10.9 & 16.9 & 14.1 \\
\hline $\mathrm{Co}$ & $\mathrm{mg} / \mathrm{kg}$ d.m. & 15 & 7.73 & 8.99 & 10.2 & 8.23 & 9.31 & 8.12 & 10.3 \\
\hline $\mathrm{Cr}$ & $\mathrm{mg} / \mathrm{kg}$ d.m. & 30 & 23.9 & 29.3 & 35.9 & 19.6 & 32.2 & 14.9 & 22.3 \\
\hline $\mathrm{Cu}$ & $\mathrm{mg} / \mathrm{kg}$ d.m. & 20 & 40.5 & 37.4 & 46.5 & 24.1 & 39.9 & 20.9 & 23.7 \\
\hline $\mathrm{Ni}$ & $\mathrm{mg} / \mathrm{kg}$ d.m. & 20 & 29.7 & 44.2 & 42.7 & 27.1 & 33.1 & 25.2 & 30.6 \\
\hline $\mathrm{Zn}$ & $\mathrm{mg} / \mathrm{kg}$ d.m. & 100 & 99.0 & 99.5 & 70.6 & 43.2 & 53.5 & 55.3 & 54.5 \\
\hline
\end{tabular}

\section{Conclusions}

The study proposes an improved microwave aqua regia extraction method for metals determination. The results obtained after digestion of two subsequent samples from CRM ERC-CC141 loam soil shows very good recovery percentages $(92 \%$ $107 \%$ ) for metal $\mathrm{Co}, \mathrm{Cr}, \mathrm{Cu}, \mathrm{Ni}, \mathrm{Pb}, \mathrm{Zn}$ concentrations, results obtained with ICP-EOS and FAAS techniques.

\section{References}

[1] Ravanbakhsh S, Zohreh M T, Fereshteh D, (2008), Microwave assisted digestion of soil, sludge and sediment for determination of heavy metals with ICP-OES and FAAS, Rasayan J. Chem.,1, 757-765.

[2] Xue Z J, Liu S. Q, Liu Y L, Yan Y L, (2012), Health Risk Assessment of Heavy Metals for Edible Parts of Vegetables Grown in Sewage-Irrigated Soils in Suburbs of Baoding City, China, Environmental Monitoring and Assessment, 184(6), 35033513.

[3] Wang M, Markert B, Chen W, Peng C, Ouyang Z J, (2012), Identification of Heavy Metal Pollutants Using Multivariate Analysis and Effects of Land Uses on Their Accumulation in Urban Soils in Beijing, China, Environmental Monitoring and Assessment, 184(10), 5889-5897. 
[4] Micó C, Peris M, Sánchez J, Recatalá L, (2006), Heavy metal content of agricultural soils in a Mediterranean semiarid area: the Segura River Valley (Alicante, Spain), Spanish Journal of Agricultural Research, 4(4), 363-372.

[5] Hernández-Mendoza H, Mejuto M, Cardona A. I, García-Álvarez A, Rocio Millán R, Yllera A, (2013), Optimization and Validation of a Method for Heavy Metals Quantification in Soil Samples by Inductively Coupled Plasma Sector Field Mass Spectrometry (ICP-SFMS), American Journal of Analytical Chemistry, 4, 9-15.

[6] Bettinelli M, Beone G M, Spezia S, Baffi C, (2000), Determination of heavy metals in soils and sediments by microwave-assisted digestion and inductively coupled plasma optical emission spectrometry analysis, 424, 289-296.

[7] Kingston H M, Haswell S J, (1997), Microwave-Enhanced Chemistry, Fundamentals, Sample Preparation and Applications, American Chemical Society, Washington DC.

[8] Thulasya Ramanathan T, Yen-Peng T,(2015), Selection of wet digestion methods for metal quantification in hazardous solid wastes, Journal of Environmental Chemical Engineering, 3, 1459-1467.

[9] Samuel Melaku S, Dams R, Moens L, (2005), Determination of trace elements in agricultural soil samples by inductively coupled plasma-mass spectrometry: Microwave acid digestion versus aqua regia extraction, Analytica Chimica Acta, 543, 117-123.

[10] Order 756/1997 - Reference Values for trace chemical elements in soil, Romanian Official Gazette part 1, no. 303 bis, 08.11.1997. 